\title{
Emancipatory Of Legal Transendency In Indonesia: Study Of Moral Aspects In The Making Of Laws And Regulations In Indonesia
}

\author{
Triwahyuningsih \\ Universitas Ahmad Dahlan \\ triwahyuningsih@ppkn.uad.ac.id
}

DOI: https://doi.org/10.23917/jtl.v1i2.9132

Submission
Track:

Received:

30 Oktober 2019

Final Revision:

05 Februari 2020

Available online:

14 Februari 2020

Corresponding

Author:

Triwahyuningsih

triwahyuningsih@ppkn.uad.ac.id

\begin{abstract}
Purposes: This paper aims to answer the question of how the relationship between law and moralism, as well as how to internalize moral principles in making laws and regulations in Indonesia.

Methodology: This study used a philosophical approach that aimed to explore the relationship between law and morals from the perspective of John Austin, Kelsen, and H. L. A Hart. It also used the transcendental perspectives in exploring the importance of internalizing moral principles in making laws and regulations in Indonesia. The research method in the article used descriptive normative research methods, with interpretative data processing techniques regarding the importance of moral aspects in making laws and regulations in Indonesia.
\end{abstract}

Findings: The dominance of the philosophy of positivism has broad implications. The closure of the law to morality raised by adherents of legalism, legal positivism, or reinerechtslehre does not only raise injustice everywhere but also appear with a face of totalitarian or repressive law. Law and moral relations, according to John Austin (1790-1859), are diametrically separated and tend to favor the law (the law negates morals), while Hans Kelsen and Austin place religious and moral inferiority while favoring positive law. According to Kelsen, the law deals with the form (formal), not the content (material); then, Hart tries to offer the principle of morality as a minimum legal requirement in which the pattern of the relationship is cooperative or independent dialogue. Whereas in the transcendent perspective, law and morals are in a dialogue-integrative relationship. The legislators should have spiritual intelligence; that is, they do not want to be bound and limited by existing standards but want to go beyond and transcend the existing situations (transcendental). With spirituality, the legislators, who are in accordance with the principle, can produce laws that show the emancipatory of legal transcendency. The laws do not only humanize humans but are also oriented to moral values that originate from God.

Importance: The benefit of this paper is to be the basis for guarding moral values in making the Law, starting from the preparation and initiative for the submission of the draft law, discussion of the draft law, and approval of the draft law.

Originality/novelty: Internalization of moral principles in law can produce laws that can make people happy and answer the problems of human life. 
At least three elements are fulfilled, namely justice, efficacy, and legal certainty.

Keywords: transcendency, morals, the formation of laws

\section{INTRODUCTION}

From a historical perspective, it can be seen that law and morals were not originally separate things, but two aspects which were united in God's law (divine law). It can be seen from the concept of Jewish law, Canon law, and Islamic law. The unification of law and morals as instruments to regulate people's lives is also reflected in the lives of people or traditional communities (underdeveloped tribes) who have not been touched by modernization. ${ }^{1}$

The separation of law and morals is influenced by the secularization of human life, which separates the worldly life that is state affairs (politics) and the affairs of the aftermath, which become the moral and religious domains. Although initially, secularization took place in the Western (Christian) world with the birth of the "renaissance," the idea of secularization has penetrated almost most parts of the world, including the Islamic world. In Indonesia, the idea of secularization also developed, which manifested itself in the discourse of the relation between state and religion, and the derivation of the pattern of that relation. ${ }^{2}$

Legal thinking that developed since the medieval era after the "renaissance" had much influence in various countries, including Indonesia. ${ }^{3}$ This school of thought (positivism) is known to have two well-known sub-schools, namely: ${ }^{4}$ An analytical positive law school that its founder of is John Austin and the pure positive law school pioneered by Hans Kelsen. The analytical positive law school defines the law as a command of the lawgiver (an order from the legislators or rulers), which is an order from those who hold the highest authority or who hold sovereignty. Law is considered as a logical, permanent, and closed system (closed logical system). The law is strictly separated

\footnotetext{
${ }^{1}$ Salman Luthan, Dialektika Hukum dan Moral dalam Perspektif Filsafat Hukum, Jurnal Hukum IUS QUIA IUSTUM No. 4, Vol 19 October 2012, page 504

${ }^{2}$ Ibid

${ }^{3}$ Lily Rasyidi, Filsafat dan Teori Hukum, Bandung: Citra Aditya Bakti, Cetakan ke-12, 2016, page 56

${ }^{4}$ Ibid, Anton F. Susanto, Ilmu Hukum Non Sistemik, Fondasi Filsafat Pengembangan Ilmu Hukum Indonesia, Yogyakarta: GENTA Publishing, 2010, page 82
} 
from morals, so it is related to justice and is not based on good or bad consideration or judgment.

In Indonesia, during the Old Order, law had become a legitimate force to maintain political power through guided democracy, having previously abolished the Gentleman's Agreement, which contained a Nationalism-Islamic concession. While in the New Order era, law was used as a tool to support development in a physical sense. On the other hand, the development of law based on indigenous and cultural wisdom, as proposed by Mochtar Kusumaatmadja, did not show a significant influence. ${ }^{5}$ Even the laws and regulations throughout the history of the New Order government, according to Soetandyo Wignjosoebroto, ${ }^{6}$ have become a controlled force in the hands of the legitimate government and did not always reflect the concepts of justice, moral principles, and real wisdom insight as they actually live in the legal awareness of ordinary people.

In the reform era, many legal products were made without a vertical foothold with the ideology of Pancasila as the morals of the Indonesian people. Pancasila ideology was no longer used as the main foothold in efforts to develop law. Many legal products appeared to be forced into their formation and were more oriented towards pragmatic interests. ${ }^{7}$ Based on data from the Constitutional Court that in 2015, 77 laws were tested in the Constitutional Court, with 157 total decisions; in 2016, 72 laws were tested, with 96 total decisions; in 2017, 58 laws were tested, with 131 total decisions. ${ }^{8}$

\section{THE FORMULATION OF THE PROBLEM}

1. What is the relationship between law and morals?

2. How to internalize moral principles in the making of laws and regulations in Indonesia?

\section{RESEARCH METHODS}

This study used a philosophical approach that aimed to explore the relationship of law and morals from the perspective of John Austin, Kelsen, and H. L. A Hart, as well as transcendental perspectives in exploring the importance of internalizing moral principles in making laws and regulations in Indonesia. The research method in the article used

\footnotetext{
${ }^{5}$ Absori, Kelik Wardiono, Saepul Rochman, Paradigma Hukum Profetik: Kritik atas Paradigma Hukum Noonsistemik, Yogyakarta: GENTA Publishing, 2018, page v

${ }^{6}$ Sidharta, Hukum Penalaran dan Penalaran Hukum, Yogyakarta : GENTA Publishing, 2013, page 392

${ }^{7}$ Absori, Cita Hukum Pancasila Ragam Paradigma Hukum Berkepribadian Indonesia, Solo : Iltizam, 2016

${ }^{8}$ http://www.mahkamahkonstitusi.go.id/index.php?page=web.RekapPUU downloaded at 14 juni 2018
} 
descriptive normative research methods, with interpretative data processing techniques regarding the importance of moral aspects in making laws and regulations in Indonesia.

\section{DISCUSSION}

The transcendence emancipatory law ${ }^{9}$ is another name for "prophetic ethical law," as concluded in Ridwan's dissertation: "Viewed from the ethical-moral point of view, the law is valid in the viewpoint of prophetic law, namely laws containing ethics content and mission, in which the ethical mission encompasses all stages and phases of law from the substance, methods, and approaches, especially the purpose of law, namely humanization, liberation, and transcendence. The ethical dimension in each phase makes the prophetic ethics have characteristics that other types of thought do not have, especially the transcendent ethics mission".

$\mathrm{K}$. Bertens put the word 'moral' by sharpening its use, whether in the context of nouns or adjectives. The word moral if used as a noun, then it is the same meaning as 'ethics.' While the word 'moral' is used as an adjective, its meaning is the same as 'ethical.' The values and norms become a guideline for a person or a group in regulating his behavior. ${ }^{10}$ Morality is the moral nature, or the whole principle and values relating to good and bad. Conditions that are contrary to good morals are referred to as immoral or amoral. ${ }^{11}$

The sources of moral teaching are traditions or customs, religious teachings, and certain ideologies. Morality includes the good and bad actions of humans. Morality can be subjective or objective. Objective morality views actions only as actions that have been done. Subjective morality is morality, which views actions as actions that are influenced by the understanding and agreement of the actor as an individual. ${ }^{12}$

According to Selznick, law is related to efforts to realize certain values. ${ }^{13}$ Meanwhile, according to Sudikno Mertokusuma, the rule of law is a provision or guideline about what should be done. ${ }^{14}$

9

, Relasi Hukum dan Moral: Studi Dalam Perspektif Pemikiran Hukum Kodrat, Positivisme Hukum dan Hukum Profetik. Disertasi, Program Doktor (S3) Ilmu Hukum Sekolah Pasca Sarjana Universitas Muhammadiyah Surakarta, 2017, page 40

${ }^{10}$ K. Bertens, Etika, Jakarta: Gramedia, 2011, page 7

${ }^{11}$ Ibid Relasi Hukum dan Moral: Studi Dalam Perspektif Pemikiran Hukum Kodrat, Positivisme Hukum dan Hukum Profetik. Disertasi, Program Doktor (S3) Ilmu Hukum Sekolah Pasca Sarjana Universitas Muhammadiyah Surakarta, 2017

${ }^{13}$ Salman Luthan, Ibid 


\section{LAW AND MORAL RELATIONS}

\section{a. Relationship of Law and Morals by John Austin's perspective}

According to John Austin (1790-1859), the law and moral relationship is diametrically separated and tends to favor the law (the law negates morals). While John Austin (1790-1859) is an analytical thinker of jurisprudence in the field of law, namely the juridical positivism, which considers law as an autonomous phenomenon that must be processed naturally. ${ }^{15}$

As the bearer of analytical jurisprudence in the field of law, namely the juridical positivism, which considers law as an autonomous phenomenon that must be scientifically processed, Austin separates the law as it is from the law as ought to be. John Austin's thoughts sharpened the conflict of legal positivism with the school of natural law. For Austin, neither God's law nor morality is actual laws. True law is a command of a lawgiver, which has the elements: sovereignty, command, duty, and sanction. In this model, positive and moral law have no association at all, including justice. The question of "What is Law and justice" will not find the answer from the thoughts of Austin and other adherents of positivism. ${ }^{16}$

Austin, as the originator of logical positivism, explained the law consists of two, namely the law of God and human-made law. Natural law, divine law, and moral law are not worth mentioning as law. It is because the aspect of the sanctions is doubtful, not in the form of orders, only based on habits. Law, according to Austin, must be distinguished from natural law, religion, and morality. Furthermore, according to Austin, the rules governing human behavior consists of three, namely God's law, positive law, and positive morality. It is as said by Constance I. Smith, quoted by Ridwan: “...Austin's purpose was to disengage law from natural law, and so from religion and morality. He divided the rules for human conduct into three: the laws of God, positive law, and positive morality...."17

\footnotetext{
${ }^{14}$ Sudikno Mertokusumo, Mengenal Hukum, Cetakan 1, Yogyakarta: Penerbit Universitas Atmajaya, 2010, page 7

${ }^{15}$ Ridwan, Relasi Hukum dan Moral, Yogyakarta: GENTA Publishing, 2017, pages 136-137

${ }^{16} \mathrm{Ibid}$

${ }^{17}$ Ibid, page 138
} 
The definition of law, according to Austin, is each positive law determined directly or indirectly by an individual or group of people authorized for a member or members of a sovereign political society, which form the law is the highest. ${ }^{18}$ It reinforces Austin's explanation that there are many kinds of laws, namely (1) God's law, which is a moral life and cannot be called true law, (1) human law, namely all the rules made by humans themselves. This human-made law consists of: (a) proper law (properly so-called law), i.e., law in the sense of laws originating from political power, or private regulations, which according to applicable law, (b) laws that are actually not legal (improper so-called law). For example, the rules that apply to a sports club, for a factory, for scientific work, etc. Such regulations are not real laws because they do not relate to the government as the lawmaker. ${ }^{19}$

\section{b. Relationship of Law and Morals by Hans Kelsen's Perspective}

Law is the order system as a system of rules about human behavior. Thus, the law does not refer to a single rule, but a set of rules that have unity, so that it can be understood as a system. As a consequence, it is impossible to understand the law if it only observes one rule. ${ }^{20}$ The statement that law is a rule about human behavior does not mean that legal order is only related to human behavior, but also with certain conditions related to human behavior. Especially in social life, there are various kinds of rules other than law, such as morals or religion. If each of these rules is different, then the definition of law must be specific, so that it can be used to distinguish the law from other rules. Each of these social rules consists of norms that have different characteristics. ${ }^{21}$

Hans Kelsen sharply separates law from morals, namely morals, as understood by the natural law school of thought from Immanuel Kant. Therefore, the legal and moral relationship in Kelsen's perspective is in the pattern of independent relations and negates each other. The two disciplines must not influence and interfere with each other because they are considered different

\footnotetext{
${ }^{18}$ Theo Huijbers, Filsafat hukum Dalam Lintasan Sejarah, Yogyakarta: Kanisius, Cetakan 18, 2007, page 43

${ }^{19}$ Ibid, page 41

${ }^{20}$ Khudzaifah dimyati, Absori, Kelik Wardiono, Fitrah Hamdani, Hukum dan Moral Basis Epispimologi Paradigma Rasional H. L.A Hart, Yogyakarta: Genta Publishing, 2017, page 35

${ }^{21}$ Ibid
} 
disciplines. Kelsen was the same as Austin, who placed religious and moral inferiority while favoring positive law. It is due to their thinking that separates the law as it is from the law as ought to be. According to Kelsen, the law deals with form, not content (material). ${ }^{22}$

For Kelsen, the content of the law is the norm, namely the meaning of the will. Law, according to Hans Kelsen, must be cleaned of non-juridical elements, such as sociology, politics, history, and morals. This kind of thinking is known as pure legal theory (reine rechtlehre). Thus, law, according to Hans Kelsen, is a sollehkategories (category of necessity/ideal), not seins categories (factual categories). Further, according to Hans Kelsen, law is a must that regulates human behavior as a rational creature, because that what is questioned by law is not what the law ought to be, but what the law is. Thus, although the law is sollehkategorie, what is used is positive law (ius constitutum), not what it aspires to (ius constituendum). ${ }^{23}$

Hans Kelsen was relatively successful when explaining the existence of a hierarchical system of positive norms. The problem only arose when he came to the top of the hierarchical system, which Kelsen gives the name Grundnorm (basic norm). This basic norm was present a priori and relatively permanent. This concept was later adopted by Hans Nawiasky, with his Staadsfundamentalnorm. The discourse on basic norms and fundamental norms of this country has actually trapped Kelsen and Nawiasky to the trap of the natural law school, as well as von Savigny when putting forward volkgeist as the soul of the nation, which must be present as a guideline for the institutionalization of social behavior. The Grundnorm concept forces legal positivism to open a little gap from the strength of argumentation and the closure of its logical system; positive norms have a peak that functions regulatively and constitutively. The hierarchical system shows the levels of norm abstraction. As a result, this basic norm is at the highest level of abstraction, which plays in the boundary area between law and morals. ${ }^{24}$

\footnotetext{
22 Ridwan, Relasi Hukum...Op. Cit., page 141

${ }^{23}$ Ibid, page 141

${ }^{24}$ Anton F. Susanto, Ilmu Hukum Non Sistemik, Fondasi Filsafat Pengembangan Ilmu Hukum Indonesia, Yogyakarta: GENTA Publishing, 2010, page 79
} 


\section{c. Relationship of Law and Morals by H. L. A. Hart's Perspective}

H. L. A. Hart accommodates morals as a legal element, and the pattern of relationship is cooperative or independent dialogue. It is the same as Kant's thought but not as the same color; Hart sees that at the end of the law, there is moral, especially in complicated cases, or in Hart language, morals must be a minimum legal element. It is caused by the dynamic development of community life, all of which cannot be accommodated by positive laws in force. ${ }^{25}$

Hart revised Kelsen's concept of legal positivism as determined norms of behavior (restricted of action) rationally. For Hart, positive law applies not solely because of the will of the authorities (as a criticism of Austin's views), nor does it because it is technically functioning (a critique of Kelsen's views). For Hart, the law applies because it is made by the ruler (positive) and reflects the behavior accepted by the majority of the community (normative). If the law can no longer be made by the authorities or the rule of law is not accepted, then the law no longer has power as the primary rules of obligations. In such circumstances (crisis of legal norms), there must be another norm principle, namely rules that change (secondary rules of obligation) to provide a place for understanding and change, according to developments in society. ${ }^{26}$

The legal and moral relationship, according to Hart, is to separate the law and morals, although Hart tries to offer the principle of morality as a minimum legal requirement. The law must be made based on moral principles, which Hart calls it as the minimum requirements of natural law, but the minimum principles of natural law are considered only as regulative principles. It means that true law remains the law even though it is against moral principles. ${ }^{27}$ Indeed, Hart does not reject the existence of law and morality, but the relationship is not absolute. Hart said equating the law with morality would bring a great danger that is causing an attitude of conservatism and anarchism. Conservatives will understand the commandments of the law in accordance with any moral command; therefore, the law becomes closed and cannot be criticized. While anarchists will do as they

\footnotetext{
${ }^{25}$ Ridwan, Relasi Hukum dan Moral, Op. Cit, pages 148-149

${ }^{26} \mathrm{Ibid}$

${ }^{27}$ Ibid, page 150
} 
please to the law. If the law is not in line with their moral outlook, they will oppose it, even at the expense of the public interest. ${ }^{28}$

\section{d. Relationship of Law and Morals by the Perspective of Emancipatory Transcendence}

The relation of law and morals from the perspective of prophetic law, according to Ridwan in his dissertation, ${ }^{29}$ shows dialog-interactive relations. It is indicated by the specific relations of object aspects that are the same in the form of the verses of Allah (explicit and implicit), aspects of the source of acquisition in the form of sensory modalities, ratios and hearts, aspects of methods and approaches that are somewhat different; morals use synthetic approaches (internalization), while law uses analytical approaches and transcendent structure methods (objectification). In the aspect of objectives, between moral and legal objectives, they are somewhat different. Moral aims at forming an Islamic Personality and a perfect Muslim person in order to gain wisdom. Whereas, the law aims to do humanization, liberation, and transcendence. These two goals form a unified objective in the form of an ethical mind that is just and egalitarian. Based on the mapping of the relationship pattern of each of these aspects, it can be concluded that in the perspective of prophetic law, the true law is law that is full of moral content and ethical ideals in each phase, and is directed to emancipate transcendence. The striking characteristic of prophetic is the placement of revelation as a pure idea while acknowledging the existence of a transcendent structure for interpreting reality. It becomes a differentiator with the school thought of natural law and legal positivism.

The prophetic paradigm is based on the epistemology assumption, in which relative morality is the result of creation and the will of absolute reality, and the norms of morality is the reality should be (sollen) created on the will of the

\footnotetext{
${ }^{28}$ Ibid, page 151

${ }^{29}$ Ridwan, Ridwan and Khudzaifah Dimyati, and Absori, RELASI HUKUM DAN MORAL: Studi Dalam Perspektif Pemikiran Hukum Kodrat, Positivisme Hukum dan Hukum Profetik. Disertasi, Universitas Muhammadiyah Surakarta, 2018
} 
authorities through a messenger with epistemological values/ethos in the form of a combination of community reality and values of revelation. ${ }^{30}$

\section{FUNCTION OF MORAL TOWARDS LAW}

In order for the law to be of benefit to society, the law must be based on morals, laws that uphold ethics, and the existing laws are not only rules but must be able to follow the development of society. Legal delays in meeting the needs of the community often occur in a codified legal system, like the Indonesian state. Such matters cannot be separated from the development of modern law, which is rational, formal, applicable to every citizen, procedural, and autonomous. Therefore, law and morals must be interrelated, so that practical law can provide protection to society. Likewise, law must be moral in both theoretical and practical settings. ${ }^{31}$

Moral has five functions concerning law, namely: ${ }^{32}$ First, morals function as an ethical basis for the formation of the rule of law. As an ethical basis, moral values form the basis of policies to form new legal norms and to renew applicable legal norms because they no longer comply with legal needs and the level of development of society. Moral values, especially the values of justice for all people and the values of virtue in the association of human life must animate and direct the formation of the rule of law (the law). The determination of rights and obligations in a legal relationship and the determination of an act as a command or prohibition must refer to the values of justice for all people and the values of virtue in the association of human life.

Second, morals are a source of law. It means that moral rules can be a source for the formation of legal norms. The implementation of the moral function as a source of law is done through the determination of acts that are not morally good (immoral) into acts that are against the law (illegal) or criminal acts. In addition, morally illegal actions are not to be determined as illegal or criminal acts. Thus, there is a significance between morality and legality with immorality or criminality.

\footnotetext{
${ }^{30}$ Khudzaifah Dimyati, Absori Absori, Kelik Wardiono, Fitrah Hamdani, MORALITY AND LAW: Critics upon HLA Hart's Moral Paradigm Epistemology Basis based on Prophetic Paradigm, Jurnal Dinamika Hukum Unsod, Volume 17-1-2017/5/2, pages 23-30, https://scholar.google.com/citations?user=dAjiP0EAAAAJ\&hl=en\&oi=sra\#d=gs_md_cita$\mathrm{d} \& \mathrm{p}=\& \mathrm{u}=\% 2 \mathrm{Fcitations} \% 3 \mathrm{Fview}$ op\%3Dview_citation\%26hl\%3Den\%26user\%3DdAjiP0EAAA, downloaded at 18 July 2018

${ }^{31}$ Subiharta, Moralitas Hukum dan Hukum Praksis sebagai suatu Keutamaan Legal Morality and Practical Law as a Virtue, Jurnal Hukum dan Peradilan Vol 4, No. 3 November 2015: 385-398

${ }^{32}$ Salman Luthan, Ibid, page 516
} 
Third, morality is a means to test (evaluate) the existence of the rule of law. Does a rule or regulation meet the qualifications of morality to be called law or not? Moreover, does the rule of law meet the qualifications of fair or good law from a moral perspective?

Fourth, morality becomes a reference justification for resolving legal cases that have no legal basis or an unclear legal basis, and fifth, moral awareness of the community can support community compliance with legal rules, especially legal rules that are in line with moral norms.

According to Fuller ${ }^{33}$, there are eight moral internal laws, namely eight values that must be realized by law. The eight values are called the eight principles of legality, namely: (1) there must be regulations first, meaning that there is no place for decisions on an ad hoc basis or arbitrary actions; (2) the regulation must be announced appropriately; (3) the rules may not apply retroactively; (4) the formulation of the regulation must be clear and detailed, its meaning must be understood by the people; (5) the law may not be carried out on impossible matters; (6) there must not be any conflict between each other; (7) rules must be fixed, may not change frequently; (8) there must be a match between the actions of the legal officials and the regulations that have been made. ${ }^{34}$

According to Hobbes to Spinosa ${ }^{35}$ interpret that the law is a clue about the good. Law is a product of human will to create cooperation and live together without violence. Human existential weaknesses, which lead to crime, are resisted and corrected through various norms (religious, moral, and legal). In the context of human nature as das Bild Gottes, legal norms, along with moral and religious norms, can be seen as a "way back" to fitrah (nature/disposition), or as a guide to return to fitrah. Since the fall in Eden (heaven), as depicted celestial religions (religions of revelation from the sky, including Islam), humans do not necessarily sink into darkness. The fall actually raises the desire to return to his noble nature, namely the desire to live rightly as a human. ${ }^{36}$

During this period of longing, various norms (rules) were used to control and even to correct the weaknesses of their existence as humans. These norms are a guide to returning to be a good human being in individual and social life. Religious norms become

\footnotetext{
${ }^{33}$ Salman Luthan, ibid page 517, read Satjipto Rahardjo, Ilmu Hukum, Bandung: Citra Aditya Bakti, Cetakan VI, 2006, page 51

${ }^{34}$ Ibid

${ }^{35}$ Khudzaifah Dimyati, Absori, Kelik Wardiono, Hukum dan Moral Basis Epispimologi Paradigma Rasional H. L.A Hart, Yogyakarta: Genta Publishing, 2017, page 31

${ }^{36}$ Ibid, page 32
} 
"transcendental guidance," moral norms become "guiding conscience," while legal norms become "public guidelines" (public norms) for the same purpose. ${ }^{37}$

As a public norm, there are several cores/essences b(imperatives), which must be made as principles of legal morality, namely: ${ }^{38}$ First, the law must belong to all people towards good; Second, because it belongs to everyone, law cannot be monopolized by certain individuals or groups (the interests of all people must be accommodated equally and equally); Third, the public guide must truly become a public space where truth, goodness, and justice are defended and maintained; Fourth, as a public guide, laws must be formed and maintained according to public values; Fifth, legal norms must be born from mutual agreement based on non-coercive communication between all groups in society; Sixth, the guards and guardians of the public guidelines are required to submit to the values and norms of the public that are inherent in the positions and duties they carry; Seventh, any betrayal of the obligation to maintain the public guidelines must be regarded as a despicable act in the public interest; Eighth, to prevent that betrayal, it is necessary to grow moral habits in the law.

\section{JUSTICE AND STATE LAW}

Cicero once said, "ubi societas ibi ius," where there are people, there is a law. Society consists of individuals who form a social community, whether intentionally or naturally. Intentionally means that the community was formed because of the same fate or suffering. ${ }^{39}$ Individuals in a society have very diverse desires; therefore, among them agree to regulate so as to create a balanced condition. This agreement among them is commonly called the norm, which consists of social norms, decency, and state norms or legal norms. ${ }^{40}$

Each country accommodates justice in the principle of national life. It is especially in the norms that are mandatory for the enactment of all laws and regulations. Roscoe Pound ${ }^{41}$ argues that the law serves to ensure social cohesiveness and social order change by balancing conflicts of interest, which include:

a. Individual interests (private interests of citizens as individuals);

\footnotetext{
${ }^{37}$ Ibid

${ }^{38}$ Khudzaifah dimyati dkk, Hukum dan Moral Basis Epispimologi Paradigma Rasional H. L.A Hart, Yogyakarta : Genta Publishing, 2017, page 33

${ }^{39}$ Muhamad Erwin, Filsafat Hukum Refleksi Kritis terhadap Hukum, Jakarta: Rajagrafindo Persada, 2011, page 236

40 Ibid

${ }^{41}$ Ibid
} 

b. Social interests (arising from the general conditions of social life);
c. Public interests (specifically state interests).

In order to balance conflicts of interest in society, state law must be entitled to justice and moral strength. Because without justice and morality, the law will lose its supremacy and independence. Instead, the idea of justice and morality of respecting humanity will only have value and benefit if it is manifested in formal law and material law and applied in people's lives. ${ }^{42}$

Justice in the formal law and material law is actually a state of balance and harmony that brings peace in people's hearts, which, if disturbed, will result in shock. People will not last long in the face of an order that they feel is totally inappropriate and unreasonable. Governments that maintain such rules will get into serious difficulties in their implementation. It means an order that is not rooted in justice is tantamount to leaning on an insecure and dangerous foundation. ${ }^{43}$

\section{TRANSCENDENCE ASPECT IN THE FORMATION OF LAW REGULATIONS IN INDONESIA}

In the context of Indonesia, the face of a law that is less moral is called the poor ideological law of Indonesian-ness because it is ahistorical. ${ }^{44}$ Absori offers a transcendental legal framework that cannot be separated from the state ideology of the Pancasila. ${ }^{45}$ Absori stated that to fill the weaknesses of the philosophical foundation of positivism thinking that is secular, liberal, value-free and deterministic in character, the elaboration of the legal positivism is needed with thoughts of a transcendental dimension, such as Prof. Tjip's progressive law, Emergency's theory from Phillip Clayton about value dialogue, and The Unity of Knowledge (Consilience) theory by Edward O. Wilson. ${ }^{46}$

Criticizing the failure of western science and civilization, Danah Zohar and Ian Marshall in "Spiritual Intelligence, The Ultimate Intelligence" introduced spiritual thinking. Ary Ginanjar Agustian combines the intellectual, emotional, and spiritual

\footnotetext{
42 Ibid

${ }^{43}$ Abdul Ghofur Anshori, Filsafat Hukum: Sejarah, Aliran dan Pemaknaan. Yogyakarta: Gajah Mada University Press, 2006, page 57

44 Ibid

${ }^{45}$ Absori, et.al. Transendensi Hukum: Prospek dan Implementasi, Yogyakarta: Genta Publishing \&Program doctor Ilmu Hukum (S3) Hukum SPs UM Surakarta, 2017, page 23

${ }^{46}$ Absori, Dekonstruksi Positivisme hukum Berdimensi Spiritual, Surabaya: Konfensi Nasional ke-3, AFHI, Universitas Airlangga\& Epistima Institute, 27-29 Agustus 2013, page 1
} 
abilities called Emotional Spiritual Quotient (ESQ) in answering the problems of human life. ESQ is a universal concept that can deliver a person to the title, satisfying himself and his fellow human beings. ESQ can also inhibit anything counterproductive to the progress of humanity. All three must be integrated; there is no separation between the world and the hereafter; the two can proportionately work together to produce a balanced mind and body strength. ${ }^{47}$

Transcendental law in the Indonesian context cannot be separated from the basic principles contained in the Pancasila ideology. The Pancasila core consists of five precepts, in the form of God, humanity, unity, society, and justice. In the field of law, the manifestation of the Pancasila ideology is elaborated in the ideals of the Pancasila Law, which function as the foundation and direction of the development and growth of national law, including the formation of laws and regulations. The ideals of the Pancasila law are interpreted as rules of community behavior that are rooted in the ideas, tastes, intentions, creations, and thoughts of the people themselves. In this case, there are three elements, namely justice, efficacy, and legal certainty. ${ }^{48}$

Thought that bases on spiritual intelligence are very interesting for the study of law in order to place the law in its essence and make law that brings happiness. Humans need spiritual quotient because, in western society, there has been a crisis in interpreting the meaning of life in the modern world (the crisis of meaning). The spiritual quotient is a tool for humans to be able to build a variety of new perspectives in life, able to find broad horizons in a narrow world, and can feel the presence of God without meeting with God. ${ }^{49}$

The demand for lawmakers to have spiritual intelligence is very urgent to be able to produce laws that bring happiness and can answer the problems of human life. At the very least, three elements can be fulfilled, namely justice, efficacy, and legal certainty, as stated above.

The spiritual intelligence does not want to be limited by standards (relu-bound); it is not only contextual but also wants to get out of the situation to seek deeper truth, meaning, or value. Thus, thinking becomes an infinite game. It does not want to be bound and limited by existing standards but wants to go beyond and penetrate the existing situation (transcendental). Spiritual intelligence does not stop accepting states and being

\footnotetext{
${ }^{47}$ Absori, dkk, Transendensi Hukum...Op., Cit, page 16

${ }^{4848}$ Ibid, page 23

${ }^{49}$ Ibid, page 17
} 
frozen but is creative and liberating. In its creation, it might work by breaking existing rules (rule-breaking) while forming new ones (rulemaking). Spiritual intelligence does not get rid of the potential of existing intelligence and emotions but increases its quality, to achieve ultimate intelligence. ${ }^{50}$

Law No. 12 of 2011 contains the main material, which is systematically compiled as follows: the principle of the formation of the Laws and Regulations; type, hierarchy, and content of the Laws and Regulations; planning the Laws and Regulations; drafting the Laws and Regulations; techniques for drafting the Laws and Regulations; discussion and ratification of the Draft Laws and Regulations; discussion and stipulation of Provincial Regulations Draft and District/City Regional Regulation Draft; promulgation of laws and regulations; dissemination; community participation in the Formation of Laws and Regulations; and other provisions that contain the formation of Presidential Decrees and other state and government institutions.

Article 5 of Law No. 12 of 2011 states that: in forming Laws and Regulations, it must be done based on the principle of the establishment of good legislation, which includes: a. clarity of purpose; b. the appropriate institutional or forming authority; c. conformity between types, hierarchy, and material content; d. can be implemented; e. usability and efficacy; f. clarity of formulation; and g. openness.

Every legal product must be based on the basic values contained in the five precepts of Pancasila, and the overall Preamble to the 1945 Constitution. There are at least four basic values that must be emanated in each of Indonesia's lawmaking and legal ideals:

a. Protect the whole nation and all Indonesian blood. This requirement is in accordance with the main ideas in the Preamble to the 1945 Constitution.

b. The law was made to realize social justice for all Indonesian people.

c. The law made must contain values and go through a democratic process. This requirement must be taken in order to obtain a responsive and populist law.

d. The law must be based on fair and civilized values of wholeness and humanity. ${ }^{51}$

\footnotetext{
${ }^{50}$ Ibid

${ }^{51}$ Absori, Fatkhul Muin , PENYUSUNAN PERATURAN DAERAH DALAM KERANGKA OTONOMI DAERAH : SUATU TINJAUAN TERHADAP PEMBENTUKAN PERDA YANG ASPIRATIF , Prosiding Konferensi Nasional Ke- 4 Asosiasi Program Pascasarjana Perguruan Tinggi Muhammadiyah (APPPTM) ISBN: 978-602-19568-1-6 https://publikasiilmiah.ums.ac.id/bitstream/handle/11617/9402/91.absori.pdf?sequence=1\&isAllowed=y downloaded at 8 Mei 2018.
} 
On the fourth basis, the formation of legislation will be oriented to values based on community interests.

Escort of moral principles in the formation of legislation can at least be carried out in (1) preparation and initiative for the submission of a draft law, (2) discussion of a draft law, and (3) approval of a draft law. While in the legalization stage and the enactment stage, it is no longer possible to strengthen and safeguard the people's sovereignty principle because both stages have no more room to make changes to the substance of the draft law. It is because a joint agreement has been made by the DPR (Parliament) and the President. ${ }^{52}$ First, the preparatory stage for submitting draft laws. Moh Mahfud M. D. ${ }^{53}$ states four legal ideals (rechtsidee), which must be used as the basis and purpose of the formation of laws and regulations:

a. General policy and legal politics must maintain national integration, both ideologically and in the territory.

b. The legal and political policy of law must be based on efforts to build democracy (popular sovereignty) and nomocracy (the rule of law) at the same time.

c. General policy and legal politics must be based on efforts to build social justice for all Indonesian people.

d. General policy and legal politics must be based on the principle of civilized religious tolerance.

Indonesia is not a religious country, so it cannot give birth to legal policies or politics based on or are dominated by one particular religion in any name. However, Indonesia is also not a secular country that has no religion, so every policy or political law must be imbued with the teachings of various religions that have noble aims for humanity. Therefore, every legal norm that is intended to be written in the form of draft laws has actually been prepared based on moral principles, mature thought, deep reflection, and solely for the public interest. It means that each draft law is not for personal or group interest..$^{54}$

\footnotetext{
${ }^{52}$ Saldi isra. Penguatan dan Pengawalan Pancasila dalam Proses Legislasi. Prosiding sarasehan Nasional Implementasi Nilai-Nilai Pancasila dalam Menegakkan Konstitusionalitas Indonesia. UGM- Mahkamah Konstitusi. 2011

${ }^{53}$ Moh. Mahfud M.D, Pancasila sebagai Hasil Karya dan Milik bersama dalam Prosiding Kongres Pancasila, Pancasila dalam Berbagai Perspektif, Sekretariat Jenderal dan Kepaniteraan Mahkamah Konstitusi, Jakarta, 2009, pages 31-33

${ }^{54}$ Ibid
} 
Second, the stage of joint discussion between the Parliament and the Government (President). There are at least three possibilities at the discussion stage of the draft law: ${ }^{.5}$
a. The proposal submitted will experience changes or improvements.
b. The proposal submitted will not experience changes or improvements.
c. If there is no mutual agreement, the draft law will be rejected so that it cannot be submitted again in the DPR session at that time.

Meanwhile, efforts to strengthen and safeguard the principle of popular sovereignty in the discussion of the law are used as a benchmark against the substance of the draft laws being discussed. Whether the discussion of draft laws of substance is really in the interests of the people, it can be said that whether the government (the President) and the Parliament (DPR) in the discussion of the law prioritize the common goals, as stated in the opening of the 1945 Constitution as mentioned above or the dominant interests of momentary (such as political and economic).

Third, the stage of mutual agreement. In Article 20 Paragraph (2) and Article 20 paragraph (3) of the 1945 Constitution, the position of the Parliament and the president is equally strong in the approval of the draft law. With such a position, the President and the Parliament should be able to use that position as a weapon to oversee the principle of popular sovereignty inherent in the institutions of the President and the Parliament. It means that if the results of the joint discussion threaten the principle of people's sovereignty, the President or Parliament must use it as a reason to refuse to ratify the draft law into law. Also, it means that the refusal to approve the draft law has a strong philosophical basis because it is contrary to the principle of popular sovereignty, which requires that all institutions tasked with formulating government policies must depend on the wishes of the people.

Therefore, in drafting laws and regulations, it must refer to several principles of drafting the laws and regulations, among others ${ }^{56}$ :

1. Safeguarding

What is meant by "the principle of safeguarding" is any material content of laws and regulations must function to protect to create public peace.

\section{Principle of Humanity}

\footnotetext{
55 Saldi Isra, Ibid

${ }^{56}$ Ibid
} 
With "the principle of humanity," every material content of the legislation must reflect the protection and respect for human rights and the value and dignity of each citizen and Indonesian population in proportion.

\section{Nationality}

"The nationality principle" is every material content of laws and regulations must reflect the diverse nature and character of the Indonesian nation while maintaining the principles of the Unitary State of the Republic of Indonesia.

4. Principle of Kinship

What is meant by "the principle of kinship" is every material content of the legislation must reflect deliberation to reach consensus in every decision-making.

5. Archipelago

With the "principle of the archipelago," every material content of legislation always takes into account the interests of the entire territory of Indonesia, and the material content of laws and regulations made in the regions is part of the national legal system based on Pancasila and the 1945 Constitution.

6. Bhinneka Tunggal Ika principle (Unity in Diversity)

What is meant by "the principle of unity in diversity" is that the content of laws and regulations must pay attention to the diversity of the population, religion, ethnicity and class, special conditions of the region and culture in the life of society, nation, and state

\section{Principle of Justice (Gerechtigheid)}

What is meant by "the principle of justice" is every material content of the legislation must reflect equal justice for every citizen.

8. Principle of Equality in Law and Government

What is meant by "the principle of equality in law and government" is any material content of laws and regulations may not contain things that are distinguished based on background, among others, religion, ethnicity, race, class, gender, or social status.

9. Principle of Order and Legal Certainty (Rechtsorde en rechrs zekerheid)

What is meant by "the principle of order and legal certainty" is any material content of laws and regulations must be able to realize order in society through guaranteed legal certainty. 


\section{Principle of Balance and Harmony}

What is meant by "the principle of balance and harmony" is every material content of legislation must reflect the balance and harmony between individual interests, society, and the interests of the nation and state.

These ten principles are then used as a benchmark in making laws and regulations in Indonesia. The ten principles are values derived from the state ideology of the Pancasila as the morals of the Indonesian people.

Pancasila, as the morals of the Indonesian people, must be a reference in making laws and regulations. Sudjito ${ }^{57}$ argues that a holistic approach in the field of law is essential to be a necessity. It is because the basic assumption in the life of the nation and state that (1) the interests of the nation and the state must be placed higher than personal and group interests; (2) in the whole life as the Indonesian nation, the existence of diversity must be respected; (3) the life of the state of law is always in the process of changing towards national ideals as stipulated in the Preamble to the 1945 Constitution, paragraph IV. Related to the effort of guarding each of the makings of legislation in the Pancasila moral framework, the holistic approach has the following relevance:

First, in the precepts of The One Almighty God. It is revealed about the harmonious relationship between a creature and its Creator. Moving on from there, Pancasila has given a voice to the soul of the Indonesian people to respect the harmonious relationship between the Creator and His creation. Therefore, Indonesian people must make every decision, attitude, or action not to damage the harmonious law between the Creator and all His creations. It is in the sense of maintaining a harmonious relationship with God, other humans, the country, and the surrounding environment. Likewise, in making laws, including in making laws and regulations, the parties involved should see in their minds that "I have God." It is why every Indonesian human being in every work, intention, and feeling will always not forget God so that they can realize justice as the goal of the law. All the principles (10 principles) of making laws and regulations, as mentioned above, are good moral values taught by God for all humankind. However, it is clearly

\footnotetext{
${ }^{57}$ Sudjito, Implementasi Nilai-nilai Pancasila dalam Menegakkan Konstitusionalitas Indonesia, Prosiding Sarasehan Nasional, kerjasama Mahkamah Konstitusi RI dengan Universitas Gajah Mada, 2011,pages 174176
} 
contrary to the Cartesian-Newtonian paradigm, which views that God has "retired" since the universe and man as its inhabitants have been created. ${ }^{58}$

The Principle of Justice is a moral value that must be presented in the formation of laws and regulations in Indonesia. It is closely related to the second precepts, Just and Civilized Humanity, showing the relationship between humans - fair - and civilized. Humans, as caliphs on earth, who, with this concept, provide an understanding of the position as ruler on earth. The demand for the establishment of the concept of responsibility is a limitation of its authority as a ruler. With this responsibility, it is made the legitimacy of the actions of the ruler (human) over all that is controlled in any form. Fair humanity lies at the point where the freedom of others is not disturbed. While civilized humanity lies in any inequality as a result of freedom, which must provide a maximum advantage or benefit for those who are not fortunate (the bottom layer in social stratification). The principles of balance and harmony demand that laws are made that humanize human beings.

The principle of Unity in Diversity is directly related to the moral values of the third principle of Pancasila, Indonesian Unity. The law that Bhinneka Tunggal Ika teaches is to love the people of Indonesia, no matter from ethnicity, religion, race, or any ethnic group; all is the same as loving oneself. Starting from this philosophy, the making of laws and regulations is always a paradigm for the integrity and glory of the nation and state of Indonesia so that the principles of nationalism and archipelago are realized.

The Principle of Order and Legal Certainty (Rechtsorde en rechrs zekerheid) is a moral value that demands that lawmakers based on the fourth principle of Pancasila "Society Led by Wisdom in Consultation/Representative," which regulate the legal relationship of power between all the people of Indonesia with the Indonesians who represent it (legislative-executive). It is to can ensure that the laws made are not multiple interpretations to create order and legal certainty.

Fifth, the principle of Social Justice for All Indonesian People, which have the legal ideals (Rechtidee) of justice presented by Indonesian lawmakers, must be accessible to all levels of Indonesian society, including children, women, people with disabilities, isolated tribal communities, human rights defenders, and isolated tribe. ${ }^{59}$

\footnotetext{
${ }^{58} \mathrm{Ibid}$

${ }^{59}$ Muhmmad Erwin, Op. Cit, pages 284-286
} 


\section{CONCLUSION}

Legal and moral relations, according to John Austin (1790-1859), are diametrically separated and tend to favor the law (the law negates morals); while, Hans Kelsen and Austin put religious and moral inferiority while favoring positive law. According to Kelsen, law deals with form, not content (material). Then, Hart tried to offer the principle of morality as a minimum legal requirement; the pattern of the relationship is cooperative or independent-dialogue, similar to Kant's thought but does not have the same color. In the emancipatory perspective, the transcendence of law and morals in the dialogue-integrative relation is indicated by the specific relation to the aspect of the same object in the form of the Verses of Allah (explicit and implied).

In the formation of laws and regulations, it must reflect the principles contained in Article 5 paragraph (1) of Law no. 12 of 2011 concerning the Formation of Laws and Regulations. These principles are a translation of the Pancasila values, which are the moral values of the Indonesian nation, including the principle of protection; humanity; nationality; kinship; archipelago; Unity in Diversity; justice; equality in law and government; order and legal certainty; and/or balance and harmony. These moral values should be guarded starting from the preparation and initiative for the submission of the draft law, discussion of the draft law, and approval of the draft law.

The legislators who have spiritual intelligence do not want to be bound by standards (relu-bound), nor are they merely contextual, but want to get out of the situation to seek deeper truth, meaning, or value. They do not want to be bound and limited by existing standards but want to go beyond and penetrate the existing situation (transcendental). Spiritual intelligence does not stop accepting states and being frozen but is creative and liberating. In its creation, it might work by breaking existing rules (rulebreaking) while forming new ones (rulemaking). Spiritual intelligence does not eliminate the potential of existing intelligence and emotions but increases its quality, to achieve ultimate intelligence to be able to produce laws that can bring happiness, can answer the problems of human life, and at least can fulfill three elements, namely justice, usefulness, and legal certainty. 


\section{REFERENCES}

Absori, Fatkhul Muin , PENYUSUNAN PERATURAN DAERAH DALAM KERANGKA OTONOMI DAERAH : SUATU TINJAUAN TERHADAP PEMBENTUKAN PERDA YANG ASPIRATIF , Prosiding Konferensi Nasional Ke- 4 Asosiasi Program Pascasarjana Perguruan Tinggi Muhammadiyah (APPPTM) ISBN: 978602-19568-1-6

https://publikasiilmiah.ums.ac.id/bitstream/handle/11617/9402/91.absori.pdf?sequence $=1 \&$ isAllowed=y diunduh, 8 Mei 2018.

Dimyati, K, Kelik Wardiono, Fitrah Hamdani, MORALITY AND LAW: Critics upon HLA Hart's Moral Paradigm Epistemology Basis based on Prophetic Paradigm, Jurnal Dinamika Hukum Unsod, Volume 17-1-2017/5/2, hal 23-30, https://scholar.google.com/citations?user=dAjiP0EAAAAJ\&hl=en\&oi=sra\#d=gs_md_cita$\mathrm{d} \& \mathrm{p}=\& \mathrm{u}=\% 2 \mathrm{Fcitations} \% 3 \mathrm{Fview}$ op\%3Dview_citation\%26hl\%3Den\%26user\%3DdAjiP0 EAAA, diunduh 18 Juli 2018

Solo: Iltizam, 2016

Cita Hukum Pancasila Ragam Paradigma Hukum Berkepribadian Indonesia, , dkk, Transendensi Hukum: Prospek dan Implementasi, Yogyakarta: Genta Publishing \&Program doctor Ilmu Hukum (S3) Hukum SPs UM Surakarta, 2017

Dekonstruksi Positivisme hukum Berdimensi Spiritual, Surabaya: Konfensi Nasional ke-3 , AFHI , Universitas Airlangga\& Epistima Institute, 27-29 Agustus 2013

Kelik Wardiono, Saepul Rochman, Paradigma Hukum Profetik: Kritik atas Paradigma Hukum Noonsistemik, Yogyakarta: GENTA Publishing, 2018.

Abdul Ghofur Anshori, Filsafat Hukum: Sejarah, Aliran dan Pemaknaan. Yogyakarta: Gajah Mada University Press, 2006.

Anton F. Susanto, Ilmu Hukum Non Sistemik, Fondasi Filsafat Pengembangan Ilmu Hukum Indonesia, Yogyakarta: GENTA Publishing

Bertens K, Etika, Jakarta: Gramedia, 2011.

Khudzaifah dimyati, Absori, Kelik Wardiono, Fitrah Hamdani, Hukum dan Moral Basis Epispimologi Paradigma Rasional H. L.A Hart, Yogyakarta: Genta Publishing, 2017

Mahfud M.D, Pancasila sebagai Hasil Karya dan Milik bersama dalam Prosiding Kongres Pancasila, Pancasila dalam Berbagai Perspektif, Sekretariat Jenderal dan Kepaniteraan Mahkamah Konstitusi, Jakarta, 2009.

Muhamad Erwin, Filsafat Hukum Refleksi Kritis terhadap Hukum, Jakarta: Rajagrafindo Persada, 2011 
Ridwan, and Khudzaifah Dimyati, and Absori, RELASI HUKUM DAN MORAL: Studi Dalam Perspektif Pemikiran Hukum Kodrat, Positivisme Hukum dan Hukum Profetik. Disertasi, Universitas Muhammadiyah Surakarta, 2018

Relasi Hukum dan Moral: Studi Dalam Perspektif Pemikiran Hukum Kodrat, Positivisme Hukum dan Hukum Profetik. Disertasi, Program Doktor (S3) Ilmu Hukum Sekolah Pasca Sarjana Universitas Muhammadiyah Surakarta, 2017

Salman Luthan, Dialektika Hukum dan Moral dalam Perspektif Filsafat Hukum, Jurnal Hukum IUS QUIA IUSTUM No. 4, Vol 19 Oktober 2012.

Saldi Isra, Penguatan dan Pengawalan Pancasila dalam Proses Legislasi. Prosiding sarasehan Nasional Implementasi Nilai-Nilai Pancasila dalam Menegakkan Konstitusionalitas Indonesia. UGM- Mahkamah Konstitusi. 2011

Satjipto Rahardjo, Ilmu Hukum, Bandung: Citra Aditya Bakti, Cetakan VI, 2006

Sidharta, Hukum Penalaran dan Penalaran Hukum, Yogyakarta: GENTA Publishing, 2013

Subiharta, Moralitas Hukum dan Hukum Praksis sebagai suatu Keutamaan Legal Morality and Practical Law as a Virtue, Jurnal Hukum dan Peradilan Vol 4, No. 3 November 2015 http://oaji.net/articles/2016/3905-1474346664.pdf diunduh 9 Mei 2018

Sudikno Mertokusumo, Mengenal Hukum, Cetakan 1, Yogyakarta: Penerbit Universitas Atmajaya, 2010.

Sudjito, Implementasi Nilai-nilai Pancasila dalam Menegakkan Konstitusionalitas Indonesia, Prosiding Sarasehan Nasional, kerjasama Mahkamah Konstitusi RI dengan Universitas Gajah Mada, 2011.

Theo Huijbers, Filsafat hukum Dalam Lintasan Sejarah, Yogyakarta: Kanisius, Cetakan 18,2007

http://www.mahkamahkonstitusi.go.id/index.php?page=web.RekapPUU 